\title{
MODEL PEMBERDAYAAN MASYARAKAT MELALUI PROGRAM COORPORATE SOCIAL REPONSIBILITY (Kasus Pelaksanaan CSR oleh PT Pertamina UP-IV Balongan)
}

\author{
Oleh: \\ Nandang Mulyana, Moch Zainuddin
}

\begin{abstract}
ABSTRAK
Pengentasan kemiskinan bukan saja tugas dari pemerintah tetapi kewajiban semua pihak termasuk perusahaan. Perusahaan khususnya BMUN mempunyai kewajiban untuk membantu masyarakat sekitar perusahaan melalui program CSR. Program CSR yang dilakukan oleh perusahaan tentunya tidak terlepas untuk memberdayakan masyarakat sekitar. Akan tetapi setiap perusahaan mempunyai model yang khas yang dikembangkan sesuai dengan visi dan misi dari perusahaan tersebut. Pelaksanaan pemberdayaan masyarakat melalui program CSR ini pada intinya dapat dilihat dari empat aspek yaitu aspek input, proses, outpur dan outcome.

Pelaksanaan Pemberdayaan masyarakat melalui program CSR yang dilakukan oleh PT Pertamina UP-IV Balongan sudah mencakup semua aspek yang ada. Dalam pelaksanaannya faktor sumber daya manusis menjadi aspek yang belum sesuai dengan kebutuhan. Sumber daya manusia yang mengurus pelaksanaan Pemberdayaan masyarakat melalui CSR di PT Pertamina UP-IV Balongan masih terbatas baik secara kuantitas maupun kualitas. Hal ini cukup menjadi kendala.
\end{abstract}

Kata kunci : Pemberdayaan masyarakat, CSR

\section{LATAR BELAKANG}

Pemberdayaan masyarakat merupakan metode yang dikembangkan dalam praktik pekerjaan sosial yang salah satu tujuannya adalah mengatasi permasalahan yang ada dalam masyarakat. Kemiskinan merupakan salah satu masalah yang dihadapi oleh negara berkembang, termasuk Indonesia. Berdasarkan data BPS masyarakat miskin berjumlah 29,89 juta orang atau 12,36\% (September 2011). Angka ini mengalami penurunan dibandingkan dengan bulan Maret 2011 yang berjumlah 30,02 juta orang $(12,49 \%)$. Jika dibandingkan dengan data tahun 2010 angka kemiskinan di Indonesia juga mengalami menurunan. Tahun 2010 jumlah masyarakat miskin di Indonesia berjumlah 31, 02 juta ( 13,33\%). Angka kemiskinan di Propinsi Jawa Barat justru memperlihatkan kenaikan. Angka kemiskinan di Jawa Barat pada bulan September 2011 berjumlah $4.650,810$ orang. Sedangkan angka kemiskinan pada bulan Maret 2011 berjumlah 4.648.630 orang. Dengan demikian terjadi peningkatan orang miskin di Propinsi Jawa Barat sejumlah 2.180 orang.

Permasalahan kemiskinan yang multidimensional ini menjadikan pemecahannya juga tidak dapat dilakukan oleh satu pihak dalam hal ini pemerintah. . Pengentasan kemiskinan yang dilakukan bukan hanya kewajiban dari pemerintah semata, tetapi kewajiban semua pihak. Untuk dapat membagi kewajiban dalam mengentaskan kemiskinan yang ada, pemerintah mengeluarkan peraturan yang mengatur pelaksanaan pengembangan 
masyarakat dalam rangka pengentasan kemiskinan. Peraturan yang dikeluarkan oleh pemerintah tersebut seperti UU Nomor 40 tahun 2007 tentang Perseroan Terbatas, yang mengharuskan bahwa setiap Perseroan Terbatas yang ada di Indonesia diharuskan melakukan Corporate Social Responsibility yang didalamnya ada pengembangan masyarakat. Peraturan lainnya adalah UU Nomor 19 tahun 2003 tentang Badan Usaha Milik Negara, dimana dalam pasal 90 mengharuskan BUMN memberikan sebagian keuntungan untuk kegiatan atau donasi sosial. Selain kewajiban pemerintah dan perusahaan, pengentasan kemiskinan juga tanggung jawab masyarakat. Pengembangan masyarakat dalam rangka mengentaskan kemiskinan dapat dilakukan melalui organisasi kemasyarakatan. Pelaksanaan pengembangan masyarakat yang dilakukan baik itu oleh pemerintah, perusahaan dalam hal ini BUMN, dan organisasi kemasyarakatan mempunyai model yang berbeda-beda. Oleh sebab itu kajian ini untuk melihat model pemberdayaan masyarakat yang dikembangkan oleh BUMN, Lembaga keagamaan dan lembaga seni.

\section{RUMUSAN MASALAH}

Pemberdayaan yang dilakukan dalam pengentasan kemiskinan pada dasarnya mempunyai model-model yang berlainan. Adakalanya model pemberdayaan masyarakat dilakukan tidak didasarkan pada konsep yang telah ada. Dengan demikian diperlukan adanya kajian dari berbagai model pengembangan masyarakat yang dilakukan baik itu oleh BUMN maupun organisasi kemasyarakatan baik itu organisasi kemasyarakatan yang didasarkan pada keagamaan maupun organisasi kemasyarakatan yang didasarkan pada kesenian. Untuk lebih memfokuskan kajian ini maka identifikasi masalah penelitian sebagai berikut:

1. Bagaimana assessment yang dilakukan oleh BUMN maupun organisasi kemasyarakatan dalam pengembangan masyarakat?

2. Bagaimana perencanaan yang dilakukan oleh BUMN maupun organisasi kemasyarakatan dalam pengembangan masyarakat?

3. Bagaimana pelaksanaan program pengembangan masyarakat yang dilakukan oleh BUMN dan organisasi kemasyarakatan?

4. Bagaimana evaluasi program pengembangan masyarakat yang dilakukan oleh BUMN dan organisasi kemasyarakatan

\section{$\begin{array}{lll}\text { TUJUAN DAN } & \text { KEGUNAAN }\end{array}$ PENELITIAN}

Kajian ini mempunyai tujuan untuk mengumpulkan dan menganalisis data tentang:

1. Assessment yang dilakukan oleh BUMN dan organisasi kemasyarakatan dalam program pengembangan masyarakat.

2. Perencanaan yang dilakukan oleh BUMN dan organisasi kemasyarakatan dalam pengembangan masyarakat.

3. Pelaksanaan program pengembangan masyarakat yang dilakukan oleh BUMN dan organisasi kemasyarakatan.

4. Evaluasi program pengembangan masyarakat yang dilakukan oleh BUMN dan organisasi kemasyarakatan.

Adapun kegunaan yang ingin dicapai dari penelitian adalah :

1. Bagi Pengembangan Keilmuan Mengembangkan kajian Ilmu Kesejahteraan Sosial yang berkaitan dengan model pengembangan masyarakat.

2. Bagi Lembaga

Mengembangkan kerja sama antara perguruan tinggi dengan lembagalembaga khususnya yang bergerak dalam pengembangan masyarakat

3. Bagi Pemerintah

Memberikan masukan kepada pemerintah dalam membuat kebijakan yang terkait dengan upaya pengembangan masyarakat. 


\section{TINJAUAN KONSEPTUAL}

Kemiskinan mempunyai dimensi yang kompleks. Kemiskinan tidak hanya bersinggungan dengan permasalahan ekonomi semata, tetapi juga berhubungan erat dengan berbagai dimensi kehidupan lainnya seperti politik, budaya maupun sosial-psikologis. Demikian kompleksnya permasalahan kemiskinan menjadikan kemiskinan sebagai permasalahan yang bersifat multidimensional. Kemiskinan didefinisikan sebagai kekurangan pendapatan untuk memenuhi kebutuhan hidup yang pokok (Salim 1980: 41). Pendapatan yang didapat tidak dapat memenuhi pangan, sandang, dan papan.

Ditinjau dari sudut dimensinya, kemiskinan dapat dilihat sebagai akibat globalisasi, kemiskinan yang berkaitan dengan pembangunan, kemiskinan sosial, dan kemiskinan konsekuensional (Cox dalam Suharto, 2004: 132-133).

Selanjutnya Kartasasmita (1996: 3) mengemukakan upaya mengatasi persoalan kemiskinan, khususnya dipedesaan yaitu :

1. Memberdayakan ekonomi masyarakat dengan memberikan modal, bimbingan teknologi, dan pemasaran untuk memandirikan masyarakat

2. Meningkatkan kualitas sumber daya masyarakat dengan peningkatan pendidikan, kesehatan, dan gizi sehingga memperkuat produktifitas dan daya saing

3. Membangun prasarana pendukung yang cukup

4. Mengatur kelembagaan yaitu kelembagaan pemerintah dan lembaga masyarakat

Program pengembangan masyarakat yang dilakukan oleh perusahaan berada dalam program yang lebih besar yaitu Corporate Social Responsibility (CSR). Definisi CSR menurut Kotler dan Lee adalah komitmen dari perusahaan untuk meningkatkan kesejahteraan masyarakat dengan menjalankan bisnis yang baik dan sebagai sumbangsih sumber daya yang dibutuhkan oleh masyarakat. Berdasarkan definisi tersebut terlihat bahwa CSR merupakan komitmen yang harus dijalankan oleh perusahaan. Hal ini bertujuan untuk meningkatkan kesejahteraan masyarakat, khususnya yang berada disekitar perusahaan, sehingga dapat menekan terjadinya kecemburuan social yang mengkin saja terjadi.

Lebih mendalam lagi bahwa CSR yang dijalankan merupakan suatu bentuk kepedulian yang diperlihatkan oleh perusahaan terhadap masyarakat. Bentuk kepedulian perusahaan ini didasari oleh prinsip dasar triple bottom lines yang meliputi :

1. Profit. Perusahaan walau bagaimanapun harus mempunyai orientasi keuntungan secara ekonomi. Hal ini disebabkan karena dengan adanya keuntungan secara ekonomi maka akan menarik investor untuk menanamkan modal usaha di suatu daerah.

2. People. Perusahan disamping mencari keuntungan secara ekonomi juga tidak serta merta mengabaikan kesejahteraan dari manusia, dalam hal ini karyawan dan masyarakat sekitar. Keuntungan besar yang diperoleh perusahaan tidak aka nada artinya jika mengabaikan kesejahteraan manusia. Hal ini dikarenakan tidak akan memunculkan rasa memiliki terhadap perusahaan yang bersangkutan yang pada suatu saat akan mengganggu perusahaan yang bersangkutan.

3. Planet. Selain mengeruk keuntungan secara ekonomi dan peduli terhadap kesejahteraan manusia, perusahaan juga harus peduli terhadap lingkungan. Hal ini didasarkan karena lingkungan merupakan salah satu penyokong keberlanjutan dari perusahaan itu sendiri. Kegagalan dalam peduli terhadap lingungan akan mendorong cepatnya perusahaan tersebut tutup (Elkington dalam Suharto, 2007).

Pelaksanaan CSR oleh suatu perusahaan selain harus didasarkan pada prinsip-prinsip tertentu, juga dilandasi oleh motif tertentu pula. Motif yang meladasi perusahaan dalam menjalankan CSR akan sangat berpengaruh terhadap tingkatan CSR yang dilaksakan. Tingkatan CSR ini dapat dikemukan sebagai berikut : 


\section{Corporate Charity}

Corporate Charity ini dapat digolongkan sebagai CSR yang dilakukan oleh perusahaan dengan didasarkan pada motif kerikatif (amal). Bentuk kegiatan yang dilakukan oleh perusahaan hanyalah untuk menyelesaikan permasalahan yang bersifat sesaat. Dampak terhadap kesejahteraan masyarakat hamper tidak terasa. Demikian juga dampak terhadap perusahaan tidak dirasakan. Sedangkan jika ditinjau dari sisi dana memerlukan dana yang besar. Pada akhirnya corporate charity ini untuk saat ini sangat jarang dilakukan, karena selain dana yang diperlukan sangat besar juga dampaknya tidak terlihat secara nyata dalam jangka panjang.

2. Corporate Philanthropy

Corporate Philanthropy ini merupakan CSR yang dilakukan oleh perusahaan dengan motif dasar pada kemanusiaan yang mempunyai sumber dari etika dan norma yang berlaku universal. Norma dan etika universal tersebut yaitu keinginan dari setiap manusia untuk menolong sesamanya. Kegiatan CSR yang dilandasi motif corporate philanthropy ini bersifat parsial dengan dasar memberikan sebagian keuntungan yang diperoleh perusahaan sebagai timbale balik dari perusahaan yang telah memanfaatkan sumber daya yang ada dalam masyarakat. Kegiatan CSR ini hanyalah kewajiban moral dimana perusahaan telah mengambil dan memanfaatkan sumber daya yang ada. Hamper sama dengan charity, Philanthropy ini juga tidak mempunyai dampak dalam jangka panjang.

3. Corporate Citizenship

Corporate Citizenship merupakan program CSR yang didasarkan pada motif kewargaan dengan tujuan untuk mencapai kemakmuran demi kepentingan semua. Dampak dari corporate citizenship ini bersifat jangka panjang baik bagi perusahaan maupun masyarakat. Hal ini disebabkan karena kegiatan CSR dengan matif ini telah dirancang sedemikian rupa sehingga akan tercipta kemandirian dan keberdayaan dari masyarakat dengan tetap memperhatian keberlanjutannya (Saidi dan Abidin 2004).

Selain itu bentuk-bentuk CSR juga bermacammacam, Bentuk dari CSR yang dilakukan oleh perusahaan adalah :

1. Bantuan Sosial (Social Assisntence)

Bantuan social merupakan bentuk CSR yang paling sederhana. Bantuan social adalah kegiatan memberikan bantuan social kepada masyarakat sebagai impelmentasi dari prinsip filantropi yang dimiliki oleh perusahaan. Bantuan social didasarkan pada asas kemanusiaan dan keinginan untuk membantu sesama. Bantuan social dilakukan oleh perusahaan bersifat parsial, karena kegiatan bantuan social bersifat satu arah, yaitu perusahaan membantu masyarakat, tanpa adanya keterlibatan masyarakat lebih jauh selain menerima bantuan yang diberikan oleh perusahaan.

2. Hubungan Masyarakat (Community Relations)

Hubungan masyarakat merupakan bentuk CSR yang lebih banyak dilakukan oleh divisi public relation (humas) yang ada dalam suatu perusahaan. Hubungan masyarakat merupakan bentuk CSR yang bertujuan untuk menjalin hubungan baik antara perusahaan dengan masyarakat. Kegiatan hubungan masyarakat ini harus bersifat srategis dengan wujud nilai-nilai sebagai berikut :

a. Secara mendasar menunjukkan nilainilai dan misi perusahaan

b. Bersifat proaktif buka reaktif

c. Memiliki visi dan tujuan yang jelas

d. Didasari pengembangan program yang substantif

e. Melakukan pemantauan, pengukuran, dan evaluasi

f. Mengharapkan bisa menghasilkan outcome dan dampak

g. Memiliki focus yang terumuskan

(Yosal Iriantara, 2007).

Salah satu bentuk dari CSR adalah pengembangan masyarakat yang merupakan model dari pembangunan komunitas dengan tujuan untuk menjadikan komunitas menjadi 
mandiri dan berdaya. Pengembangan masyarakat merupakan program yang disusun oleh perusahaan untuk meningkatkan pertumbuhan ekonomi, keadaan lingkungan, pendidikan, keahlian, kesehatan, dan kesejahteraan dari stakeholder perusahaan, terutama bari mereka yang tinggal berdekatan atau dipengaruhi oleh kegiatan perusahaan (Nigam, 1999).

Selain itu pengembangan masyarakat sebagai salah satu bentuk dari CSR yang saat ini banyak dikembangkan mempunyai prinsipprinsip tertentu. Ife mengemukakn prinsipprinsip pengembangan masyarakat sebagai berikut :

\section{Integrated Development}

Kegiatan pengembangan masyarakat harus merupakan sebuah pembangunan yang terintegrasi, yang dapat mencakup berbegai aspek kehidupan manusia

2. Human Right

Kegiatan pengembangan masyarakat harus dapat menjamin adanya pemenuhan hak bagi setiap manusia untuk hidup secara layak dan baik

3. Sustainability

Kegiatan pengembangan masyarakat tidak hanya untuk kepentingan sesaat, namun harus memperhatikan sifat keberlanjutan dari kegiatan yang dilaksanakan

4. Empowerment

Pemberdayaan merupakan tujuan dari pengembangan masyarakat. Pemberdayaan mengandung pengertian menyediakan sumber-sumber, kesempatan, pengetahuan, dan ketrampilan kepada masyarakat untuk meningkatkan kapasitasnya agar dapat menentukan masa depannya dan dapat berpartisipasi dalam kehidupan masyarakat dan mempengaruhi kehidupan masyarakat

5. Self-Reliance

Kegiatan pengembangan masyarakat sedapat mungkin memanfaatkan berbagai sumber yang dimiliki oleh masyarakat daripada menggantungkan kepada dukungan dari luar
6. Organic Development

Kegiatan pengembangan masyarakat merupakan proses yang kompleks dan dinamis, dan masyarakat juga mempunyai sifat yang organic. Oleh sebab itu penyelesaian msalah yang ada dalam masyarakat sepenuhnya ditentukan oleh kondisi dan situasi masyarakat itu sendiri

7. The Integrity of Process

Pengembangan masyarakat bukan hanya mementingkan pencapaian hasil, melainkan proses

8. Co-operation

Pengembangan masyarakat lebih membutuhkan struktur yang kooperatif

9. Participation

Pengembangan masyarakat sedapat mungkin memaksimalkan partisipasi masyarakat, dengan tujua agar setiap orang dapat terlibat secara aktif dalam aktivitas dan proses masyarakat. Partisipasi ini juga harus didasarkan kepada kesanggupan masing-masing anggota masyarakat.

\section{HASIL KAJIAN}

\section{Karateristik Informan}

Informan yang diambil dalam penelitian ini adalah informan yang berasal dari PT Pertamina UP-IV Balongan yang merupakan berkaitan dengan pelaksanaan CSR oleh BUMN. Pemilihan informan dari PT Pertamina UP-IV Balongan ini dikarenakan pihak PT Pertamina UP-IV Balongan yang melaksanakan CSR khususnya dalam bentuk pengembangan masyarakat. Informan yang berasal dari pihak PT Pertamina UP-IV Balongan berjumlah 4 orang yang berasal dari divisi Hupmas dan PKBL.

\section{Pelaksanaan CSR dari Aspek Input, Proses, Output, dan Outcome \\ a. Pelaksanaan CSR PT Pertamina UP-IV ditinjau dari Aspek Input}

Pelaksanaan suatu program akan berjalan dengan baik dan maksimal jika ada input yang sesuai dengan kebutuhan. Input yang dibutuhkan dalam program CSR PT 
Pertamina UP-IV Balongan meliputi sumber daya manusia, sumber dana, target pencapaian dari program, masyarakat penerima manfaat, dan stakeholders yang terlibat dalam program.

Sumber dana dari program CSR didasarkan kepada Surat Keputusan Menteri BUMN No. 005 tahun 2007 tentang Program Kemitraan dan Bina Lingkungan Badan Usaha Milik Negara. Berdasarkan keputusan Menteri BUMN tersebut ada ketentuan bagi semua BUMN harus melakukan program CSR dalam bentuk :

a. Program Kemitraan

1. Penyisihan laba BUMN setelah dikurangi pajak sebesar 1-3\%

2. Hasil bunga pinjaman, bunga deposito dan jasa giro dari dana program kemitraan setelah dikurangi beban oparasi.

3. Untuk hibah kemitraan, ditetapkan maksimal $20 \%$ dari dana program kemitraan yang disalurkan pada tahun berjalan.

b. Program Bina Lingkungan

1. Penyisihan laba setelah pajak maksimal $1 \%$.

2. Hasil bunga deposito dan atau jasa giro dari dana Program Bina Lingkungan.

PT Pertamina UP-IV Balongan menyisihkan sebagian keuntungannya untuk program CSR dan Kemitraan. Program Kemitraan dan Bina Lingkungan (PKBL), dari perusahaan diserahkan kepada PKBL di unit operasi yang selanjutnya digunakan di masingmasing unit operasi yang ada. Adapun dana CSR PT Pertamina UP-IV Balongan berasal dari dana operasional (RKAP) yang dikeluarkan oleh divisi Hupmas.

Berdasarkan informasi ada perbedaan mengenai dana program dari PKBL dengan CSR. Lebih jelasnya perbedaan alokasi dana antara PKBL dengan CSR dapat dilihat pada tabel 5.1 sebagai berikut :
Tabel 1

Pengelolaan program PKBL dengan CSR PT Pertamina UP-IV Balongan

\begin{tabular}{|l|l|l|}
\hline & \multicolumn{1}{|c|}{$\begin{array}{c}\text { Program } \\
\text { comdev } \\
\text { (Hupmas) }\end{array}$} & \multicolumn{1}{c|}{ PKBL } \\
\hline $\begin{array}{l}\text { Sumber } \\
\text { dana }\end{array}$ & $\begin{array}{l}\text { Biaya Operasi } \\
\text { (RKAP) }\end{array}$ & $\begin{array}{l}\text { Laba perusahaan } \\
\text { setelah pajak, } \\
\text { merupakan } \\
\text { bagian dari laba } \\
\text { pemerintah }\end{array}$ \\
\hline Peruntukan & $\begin{array}{l}\text { Bantuan pihak } \\
\text { ketiga/ kegiatan } \\
\text { yang dapat } \\
\text { meningkatkan } \\
\text { citra perusahaan }\end{array}$ & $\begin{array}{l}\text { Lima aspek yang } \\
\text { ditentukan } \\
\text { bencana alam, } \\
\text { sarana umum, } \\
\text { pendidikan, } \\
\text { kesehatan, sarana } \\
\text { ibadah }\end{array}$ \\
\hline $\begin{array}{l}\text { Pertanggung } \\
\text { jawaban }\end{array}$ & $\begin{array}{l}\text { Informal dan } \\
\text { perusahaan } \\
\text { (direksi untuk } \\
\text { korporat) dan } \\
\text { GM untuk unit } \\
\text { operasi }\end{array}$ & $\begin{array}{l}\text { Informal } \\
\text { eksternal (kepada } \\
\text { pemerintah) audit } \\
\text { oleh BPKP }\end{array}$ \\
\hline Hasil penelitian yang telah
\end{tabular}

dimodifikasi

\section{b. Sumber Daya Manusia yang melaksanakan CSR}

Secara kuantitas sumberdaya manusia di PT Pertamina UP-IV Balongan berjumlah 7 orang yang terbagi atas staf Hupmas berjumah 2 orang dan sisanya 5 orang merupakan pegawai tidak tetap yang bertugas membantu pelaksanaan tugas harian baik di kantor maupun dalam pelaksanaan program CSR. Demikian juga di PKBL berjumlah 7 orang. Ditinjau dari aspek pendidikannya staf Hupmas maupun PKBL sudah mempunyai pendidikan sarjana, akan tetapi pegawai tidak tetap lebih banyak berpendidikan SMA. Kondisi ini memperlihatkan bahwa secara kuantitas maupun kualitas pelaksana program CSR dan PKBL di PT Pertamina UP-IV Balongan masih belum maksimal. sangat kurang. Sumber daya manusia di PT Pertamina UP-IV masih kekurangan sumber daya manusia baik secara kunatitas maupun kualitas. Secara kuantitas dengan jumlah yang ada sekarang ini sangat tidak ideal. Hal ini disebabkan karena banyaknya program CSR maupun PKBL yang harus dilaksanakan. Selain itu juga luasnya daerah yang menjadi 
cakupan kegiatan CSR maupun PKBL memerlukan pelaksana yang lebih banyak. Kemudian secara kualitas kekurangan ini terlihat masih banyak pelaksana yang berpendidikan SMA. Diperlukan pelaksana yang benar-benar ahli dalam bidang CSR dengan kaulifikasi pendidikan tinggi.

\section{c. Penerima Manfaat}

Penentuan penerima manfaat dari program CSR PT Petamina UP-IV Balongan didasarkan kepada pembagian wilayah. Dasar dari pebagian wilayah adalah lokasi desa, dampak langsung yang ditimbulkan dari operasional, ukuran dan dana yang disediakan. Pembagian wilayah pelaksanaan CSR oleh PT Pertamina UP-IV Balongan adalah :

2. Wilayah Kilang UP-IV Balongan (Desa Majakerta, Sukaurip, Balongan)

3. Wilayah Kilang LPG Mundu

4. Wilayah WTP Salamdarma

5. Wilayah Perumahan Bumi Patra

6. Wilayah SBM/SPM

Sementara mekanisma yang dijalankan oleh PT Pertamina UP-IV Balongan dalam pelaksanaan program CSR melalui :

7. Bottom Up Process

Program CSR yang didasarkan atas permintaan dari masyarakat, yang selanjutnya dievaluasi oleh PT Pertamina UP-IV Balongan. Contoh kegiatan CSR yang menggunaan mekanisme ini adalah perbaikan kantor Camat Balongan, perbaikan Masjid di Desa Majakerta

8. Top Down Process

Mekanisme ini didasarkan pada survey yang dilakukan oleh PT Pertamina UP-IV Balongan yang juga disetujui oleh masyarakat sekitar. Contoh kegiatan CSR dengan mekanisme ini adalah pelatihan calon TKW di Kecamatan Balongan.

\section{d. Pelaksanaan CSR PT Pertamina UP-IV ditinjau dari Aspek Proses}

Pelaksanaan program CSR PT

Pertamina UP-IV Balongan dari aspek proses ini terbagi menjadi :

\section{Program Community Development}

Program CSR yang dilakukan oleh PT Pertamina UP-IV Balongan secara ideal diarahkan dapat menyentuh langsung kebutuhan masyarakat. Program yang dibuat meliputi program community development, community assistance, dan community relation yang merupakan bagian dari program CSR yang dilaksanakan. Program community assistance dan community relation lebih diarahkan untuk meningkatkan hubungan antara perusahaan dengan masyarakat. Dengan demikian kegiatan community assistance dan community relation lebih banyak bersifat temporer sesuai dengan kebutuhan. Tidak ada program yang terstruktur dengan perencana yang matang untuk melaksanakan program community assistance dan community relation. Berbeda dengan program community development yang kegiatannya direncanakan dengan matang dan dilakukan untuk membantu pembangunan dan meningkatkan IPM yang meliputi bidang pendidikan, kesehatan, dan perekonomian.

\section{e. Pelaksanaan CSR PT Pertamina UP-IV ditinjau dari Aspek Output}

Output dari pelaksanaan program CSR yang dilakukan oleh PT Pertamina UP-IV Balongan mengacu pada perencanaan dan pelaksanaan program CSR. Outpur merupakan hasil yang didapat dari pelaksanaan CSR yang dilakukan oleh PT Pertamina UP-IV Balongan. Seperti diketahui bahwa perencanaan dan pelaksanaan program CSR yang dilakukan oleh PT pertamina UP-IV Balongan diarahkan kepada bidang pendidikan, kesehatan, dan peningkatan perekonomian masyarakat. Adapun output yang didapat dalam bidang pendidikan yaitu dengan memberikan bantuan untuk peningkatan fasilitas pendidikan seperti pemberian saraan alat peraga, perbaikan gedung sekolah, pengadaan buku dan komputer dan pelatihan guru.

Pelaksanaan program CSR di bidang kesehatan bersifat insidental dengan tekanan pada pemberian bantuan sosial dibidang kesehatan. Sementara itu program CSR yang berkaitan dengan peningkatan ekonomi 
masyarakat tidak terlepsa dari program PKBL yang menjadikan masyarakat sebagai mitra binaan. Bantuan yang diberikan mulia dari permodalan sampai dengan pemasaraan produk yang dihasilkan oleh masyarakat. Program CSR lainnya adalah pembangunan fasilitas umum yang meliputi pembangunan musholla di setiap dusun yang termasuk ring 1, pembangunan jalan.

\section{f. Pelaksanaan CSR PT Pertamina UP-IV ditinjau dari Aspek Outcome}

Outcome merupakan dampak lanjutan dari pelaksanaan program CSR yang dilakukan oleh PT Pertamina UP-IV Balongan. Outcome yang dirasakan tidak hanya oleh masyarakat dengan berbagai program CSR. Outcome juga dirasakan oleh PT Pertamina UP-IV Balongan. Manfaat yang dirasakan oleh PT Pertamina UP-IV Balongan dari program CSR yang telah dilakukan adalah terciptanya iklim usaha yang semakin kondusif. Potensi konflik yang seringkali terjadi semakin menghilang. Selain itu juga semakin baiknya image perusahaan yang tidak hanya mengejar keuntungan juga memperhatikan masyarakat sekitar perusahaan.

Sementara itu keuntungan yang dirasakan oleh masyarakat meliputi masyarakat terbantu dengan semua bantuan yang dilakukan oleh PR Pertamina UP-IV Balongan. Sulitnya akses untuk mendapaykan modal maupun terhadap sarana pendidikan dan kesehatan sudah mulai teratasi Selain itu juga munculnya rasa memiliki yang diperlihatkan oleh masyarakat terhadap PT Pertamina UP-IV Balongan.

\section{KESIMPULAN DAN SARAN}

\section{Kesimpulan}

Berdasarkan hasil penelitian maka dapat ditarik kesimpulan bahwa pemberdayaan masyarakat yang dilakukan oleh PT Pertamina UP-IV Balongan sudah menunjukkan kelengkapan mulai dari input, proses, output sampai dengan outcome. Dalam pelaksanaanya pemberdayaan masyarakat yang dilakukan oleh PT Pertamina UP-IV Balongan masih didasarkan kepada aturan yang mengharuskan dilakukannya progam CSR. Terlepas dari itu semua kegiatan dalam pemberdayaan masyarakat melalui program CSR yang dilakukan oleh PT Pertamina UP-IV sudah dirasakan manfaatnya oleh perusahaan maupun masyarakat sekitarnya.

2. Saran

a. Program CSR yang dilaksanakan oleh PT Pertamina UP-IV Balongan harus diarahkan kepada pengembangan masyarakat dengan mengacu kepada partisipasi masyarakat dalam semua tahapan CSR.

b. Meningkatkan koordinasi pelaksana program CSR dilapangan sehingga dapat meminimalkan konflik serta adanya pembagian kerja yang jelas sehngga tidak terjadi tumpang tindih.

\section{DAFTAR PUSTAKA}

Adi, Isbandi Rukminto, 2007, Pemberdayaan, Pengembangan Masyarakat dan Intervensi Komunitas, Lembaga Penerbit UI, Jakarta

Arsyad, Lincoln, 2008, Lembaga Keuangan Mikro: Institusi dan Sustainabilitas, ANDI, Yogyakarta

Budimanta, Arif, 2003, Cetak Bitu Pengelolaan Community

Development, ICSD, Jakarta. 2003, Metode dan Tekhnik

Pengelolaan Community

Development, ICSD, Jakata.

Iriantara, Yosal, 2004, Community Relations, Konsep dan Aplikasinya, Bandung Simbiosa Rekatama Media.

Kartasasmita, Ginanjar, 1996, Pembangunan Untuk Rakyat: Memadukan Pertumbuhan dan Pemerataan, CIDES, Jakarta

Suharto, Edi, 2005, Membangun Masyarakat Memberdayakan Masyarakat, Refika Aditama, Bandung. 2007, Pekerjaan Sosial di Dunia Industri, Refina Aditama, Bandung.

Tim Pelatihan Laboratorium Kesejahteraan Sosial, 2004, Pelatihan Pengembangan Masyarakat dan Akuntabilitas Publik. 